\title{
Interruption of CD40 Pathway Improves Efficacy of Transplanted Endothelial Progenitor Cells in Monocrotaline Induced Pulmonary Arterial Hypertension
}

\author{
YanYun Pan ${ }^{\mathrm{a}}$ Shuai Wang ${ }^{\mathrm{a}}$ JinXiu Yang ${ }^{\mathrm{b}}$ Bin Chen ${ }^{\mathrm{c}}$ ZeWei Sun ${ }^{\mathrm{a}}$ LiFang Ye $^{\mathrm{a}}$ \\ JianHua Zhu ${ }^{a}$ XingXiang Wang ${ }^{a}$ \\ aDepartment of Cardiology, The First Affiliated Hospital, School of Medicine, Zhejiang University, \\ Hangzhou, Zhejiang, PR China, 'bepartment of Cardiology, The First Affiliated Hospital, Zhejiang \\ Chinese Medical University, , Hangzhou, Zhejiang, PR China, 'Department of Cardiology, Hangzhou \\ First Peoples Hospital, Hangzhou, Zhejiang, PR China
}

\section{Key Words}

Endothelial progenitor cells • CD40/CD40L • Pulmonary arterial hypertension

\begin{abstract}
Background/Aims: Transplantation of endothelial progenitor cells (EPCs) plays a therapeutic role in pulmonary arterial hypertension (PAH). Meanwhile, recruitment of progenitors has potential inflammatory effects and exaggerates vascular injury. CD40 pathway is identified as a major player in vascular inflammatory events. In this study, we investigated the role of CD40 pathway in regulating early outgrowth EPC functions, and searched for improvements in PAH cell therapy. Methods: EPCs were isolated from rat bone marrow and cultured for 7 days. After treatment with soluble CD40 ligand (sCD40L) for 24 hours, EPC migration, adhesion, proliferation, paracrine and vasculogenesis functions were tested. Rat PAH model was founded by subcutaneous injection of monocrotaline (MCT). Control EPCs or lentivirus vectors (Lv)shRNA-CD40 EPCs were infused via tail vein at day 7, 14, and 21 after MCT injection. Therapeutic effects were evaluated at day 28. Results: sCD40L dose-dependently impaired EPC migration, adhesion, proliferation, and vasculogenesis functions. However, paracrine effects of soluble intercellular adhesion molecule-1, vascular endothelial growth factor and interleukin- 6 were dose-dependently improved by sCD40L. Control EPC-derived conditioned medium protected endothelial cell in vitro vasculogenesis, while sCD40L-pretreated ones showed detrimental effects. After MCT injection, SCD40L levels in rat serum increased gradually. Other than in vitro results, benefits of both two EPC treatments were obvious, even taken at day 21. Benefits of control EPCs wore off over time, but those of LV-shRNA-CD40 EPCs were more effective and enduring, as characterized by both ameliorated rat hemodynamic and reversed vascular remodeling. Furthermore, Lv-shRNA-CD40 EPCs integrated into endothelium better, rather than into adventitia and media. Conclusion: sCD40L impaired protective effects of EPCs. Traditional EPC treatments were limited in PAH, while interruption of CD40 pathway of transplanted cells could apparently improve the therapeutic efficacy.
\end{abstract}

Copyright $(2015$ S. Karger AG, Basel

XingXiang Wang, PHD

JianHua Zhu, MD/PHD,

KARGER 125
Department of Cardiology, The First Affiliated Hospital, School of Medicine, Zhejiang University, 79 Qingchun Road, Hangzhou, Zhejiang, (PR China)

E-Mail wangxx0571@aliyun.com, E-Mail zhujianhua2006@hotmail.com 


\section{Cellular Physiology Cell Physiol Biochem 2015;36:683-696

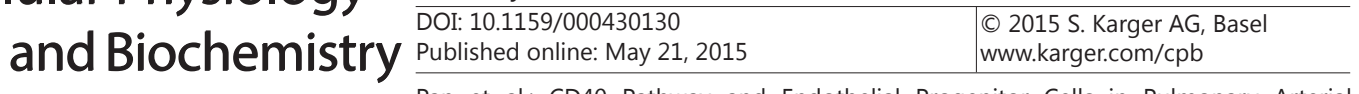 \\ Pan et al.: CD40 Pathway and Endothelial Progenitor Cells in Pulmonary Arterial Hypertension}

\section{Introduction}

Endothelial progenitor cells (EPCs) are specific mononuclear cells playing important roles in vascular repair and regeneration, mainly identified in the bone marrow (BM), cord, and peripheral blood [1]. The lack of standards on surface markers is important for application of EPCs, and all markers are under dynamic development and change [1]. But still, most of the so called EPCs are reported to have similar effects on assisting angiogenesis [2]. They exert their functions in two predominant ways: by differentiating into mature endothelial cells (ECs) and by secreting cytokines [1-3]. Their amount and viability are usually reduced in diseased individuals, thus are considered to be the reflection of endogenous angiogenic capacity and novel biomarkers to assess the severity of cardiovascular diseases [4]. Cumulative experimental and clinical evidence suggests that transplantation of in vitro expanded EPCs has therapeutic effects in endothelium injury diseases including pulmonary arterial hypertension (PAH), as a potential strategy in regenerative medicine [5-10]. Our group is engaging in improving EPC application in PAH $[1,11]$.

Conversely, some researchers have reported inefficacy results of cell transplantation $[12,13]$. In addition to inconsistencies on cell subpopulations and the corresponding capabilities [2], EPCs have been related to inflammatory responses and arterial remodeling for participation in vasa vasorum and secretion pro-inflammatory factors $[1,14-16]$. So it is still debatable about the roles of EPCs in disease treatment.

Pathological microenvironments in disease models are considered to play crucial roles in regulating outcomes of cell therapies. Elevated circulating levels of inflammatory cytokines (eg, interleukin [IL]-1 and IL-6), several chemokines (eg, macrophage inflammatory protein-1 and monocyte chemoattractant protein-1), and perivascular infiltration of inflammatory cells (eg, T cells and macrophages) have been found in PAH $[17,18]$. Inflammatory environment has been associated with impaired viability and recruitment of EPCs [19]. Asosingh et al. further suggest that control progenitor cells are beneficial to the PAH mice, whereas PAH ones may exacerbate endothelial injury [20].

Recently, EPC transplantation combined with gene transfer like adrenomedullin [5], eNOS [7] and prepro-calcitonin [6], or drugs like cilostazol [8] and sildenafil [9] were reported to have superior results over EPCs only. However, modified EPC therapy aiming at anti-inflammation for PAH treatment is relatively rare.

Increased plasma levels of soluble CD40 ligand (sCD40L) are typical representatives of inflammatory related pathophysiological changes in PAH [17, 21]. CD40 belongs to the superfamily of tumor necrosis factor receptors, and SCD40L (CD154) is a member of the tumor necrosis factor superfamily. The engagement of sCD40L and its receptor CD40 in cell surface can ignite and amplify inflammatory and coagulatory activities of vascular endothelium by regulating immune and non-immune cells, namely, monocytes, dendritic cells, fibroblasts, smooth muscle cells, macrophages, and ECs [22, 23]. Blockade of CD40L-CD40 interactions has been proved to prevent the development of acute and chronic inflammation [24]. Current drugs that inhibiting the CD40/CD40L system including antiplatelet, antitumor and immunosuppressive drugs gain benefits in clinical applications especially in atherosclerosis and carcinomas $[23,25]$. More recently, the system is gaining much attention for its role in the initiation and progression of PAH [17]. But it is still unclear whether specific treatments targeting CD40 pathway can be beneficial in PAH, and their effects on transplanted EPCs are yet to be further addressed.

In this study we were prompted to investigate the potential effects of CD40 pathway on regulating transplanted EPC functions and the application in PAH.

\section{Materials and Methods}

Isolation and cultivation of EPCs

Our study was approved by the institutional animal care committee of Zhejiang University and complied with the Guide for the Care and Use of Laboratory Animals. All rats were purchased from Charles 


\section{Cellular Physiology Cell Physiol Biochem 2015;36:683-696 \\ \begin{tabular}{ll|l} 
and and 10.1159/000430130 & $\begin{array}{l}\text { C } 2015 \mathrm{~S} \text {. Karger AG, Basel } \\
\text { www.karger.com/cpb }\end{array}$ \\
\hline
\end{tabular} \\ Pan et al.: CD40 Pathway and Endothelial Progenitor Cells in Pulmonary Arterial Hypertension}

River (China). According to established protocols [7, 12], EPCs were isolated from femurs of 4 to 5 weeks old male Sprague-Dawley rats by density gradient centrifugation with ficoll (Histopaque 1083; Sigma) and suspended in EBM-2 medium (Lonza) supplemented with 10\% FBS (Gibco). After 24h, only the non-adherent cells were harvested and cultured on fibronectin-coated 6-well plates (Corning) with fresh EBM-2 medium supplemented with EGM-2 MV single aliquots, containing $10 \% \mathrm{FBS}$ at $37^{\circ} \mathrm{C}$ with $5 \% \mathrm{CO}_{2}$. The medium was changed four days later and then every day. EPCs were harvested and subjected to functional analysis or transplantation at day 7. Some EPCs were incubated with recombinant murine sCD40L (PeproTech) at 0.1, $0.5,1$ or $2 \mu \mathrm{g} / \mathrm{ml}$ for $24 \mathrm{~h}$ at day 7 .

\section{Characterization of EPCS}

The classical method for the identification of EPCs was fluorescent chemical detection $[5,7,12]$. EPCs harvested at day 7 were incubated with $10 \mu \mathrm{g} / \mathrm{ml}$ acetylated low density lipoprotein labeled with 1, 1'-dioctadecyl-3, 3, 3', 3'-tetramethylindo-carbocyanine (DiI-ac-LDL; Molecular Probe) for $4 \mathrm{~h}$ at $37^{\circ} \mathrm{C}$. Then fixed with $4 \%$ paraformaldehyde for $10 \mathrm{~min}$, and stained with $10 \mu \mathrm{g} / \mathrm{ml}$ fluorescein isothiocyanate (FITC)-conjugated Ulex europaeus agglutinin (UEA)-I (Sigma) for 1h. Double positive cells identified with fluorescence microscope were considered to be EPCs.

EPCs were trypsinized and incubated with two endothelial-related antibodies: anti-vascular endothelial growth factor receptor 2 (anti-VEGFR2, Abcam) and FITC-conjugated von Willebrand factor (vWF, Abcam). FITC-conjugated anti-mouse antibody (Vector) was added to link with VEGFR2. Respective control antibodies were matched to isotype and fluorochrome. Sample tubes were acquired and analyzed by a FACStar flow cytometer (Beckman Coulter).

Lentivirus vectors for CD40 small hairpin RNA (shRNA) and cell infection

A third-generation self-inactivating lentivirus vector containing a CMV-driven GFP reporter and a U6 promoter upstream of the cloning restriction sites (BamHI and EcoRI) was used. Coding regions corresponding to targeting rat CD40 starting at positions (5' GCTCTTGAGAAGACCCAATGC3') in the sequence (GenBank Accession: NM_134360.1) were selected as target sequences under the guide of designing software offered by GenePharma Co., Ltd, Shanghai, China. The lentivirus vectors (Lv)-NC-shRNA served as a negative control. Lv-shRNA-CD40 was constructed and validated by Genepharma for interference of CD40 gene expression and protein synthesis. The virus titers produced were approximately $10^{9} \mathrm{TU} / \mathrm{ml}$ medium. EPCs were infected with Lv-shRNA for 18h at a multiplicity of infection (MOI) of 100. Polybrene was added to each well at a concentration of $5 \mu \mathrm{g} / \mathrm{ml}$. The inhibition efficiency of Lv-shRNA on CD40 RNA and protein was tested using real time PCR and Western blot (Fig. 1A-D).

\section{Transmigration Assay}

EPC transmigration was assessed with the use of transwell 24-well plate (Corning). In summary, adherent cells were trypsinized, counted, and resuspended in EBM-2 medium. Medium with cells $\left(3 \times 10^{4}\right)$ was placed in the upper chamber of a transwell chamber. EBM-2 medium containing 10\% FBS was placed in the lower compartment of the well. After $12 \mathrm{~h}$ incubation at $37{ }^{\circ} \mathrm{C}$ with $5 \% \mathrm{CO}_{2}$, cells migrated to the bottom surface of the filter. For quantification, cells were fixed with $4 \%$ paraformaldehyde, stained with $0.1 \%$ crystal violet solution, and counted under ordinary microscope (Leica).

\section{Adhesion assay}

Cells were trypsinized, counted, and resuspended in EBM- 2 medium. Medium with cells $\left(3 \times 10^{4}\right)$ was added into 24-well plate, and incubated for $10 \mathrm{~min}$ at $37^{\circ} \mathrm{C}$ with $5 \% \mathrm{CO}_{2}$. After gently washing with PBS, adherent cells were counted by independent blinded investigators in five randomly chosen microscopic fields (Leica).

\section{Proliferation Assay}

Cells were trypsinized, counted, and reseeded on a 96-well plate at day 6. 24h later, fresh EBM-2 with sCD40L was added. Proliferative function was assessed with the use of the Cell Counting Kit-8 (Dojindo), according to the manufacturer's protocol.

\section{KARGER}




\section{Cellular Physiology Cell Physiol Biochem 2015;36:683-696 \\ \begin{tabular}{ll|l} 
and Biochemistry & $\begin{array}{l}\text { DOI: 10.1159/000430130 } \\
\text { Published online: May 21, } 2015\end{array}$ & $\begin{array}{l}\text { (c) 2015 S. Karger AG, Basel } \\
\text { www.karger.com/cpb }\end{array}$ \\
\cline { 2 - 3 }
\end{tabular} \\ Pan et al.: CD40 Pathway and Endothelial Progenitor Cells in Pulmonary Arterial Hypertension}

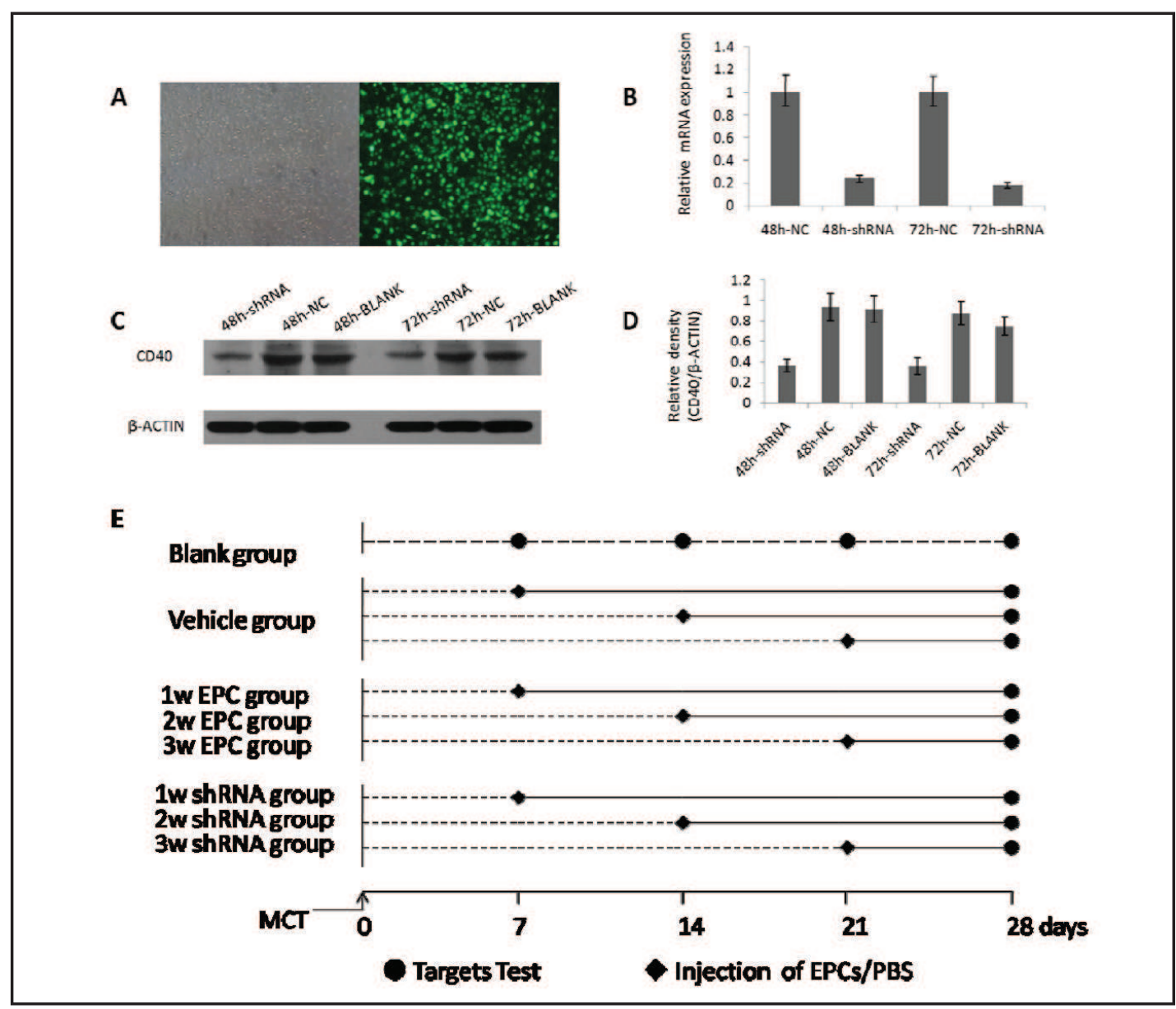

Fig. 1. Lv-shRNA-CD40 efficiency and animal experimental design. EPCs infected with lentiviral vectors showed green under fluorescent microscope $(A, \times 100)$. The inhibition efficiencies of CD40 RNA and protein were tested with qPCR (B, n=9) and Western blot (C, D, n=3). Lv-NC-shRNA infected EPCs were served as negative controls (NC). Pathological changes of PAH rats in blank group were tested every week after MCT injection. Vehicle group with PBS injection worked as a negative control for the cell transplantation groups. Control EPCs or shRNA-CD40 EPCs were injected every week in batches, and their efficacies were tested at day $28(\mathrm{E})$.

\section{In vitro vasculogenesis assay}

Vasculogenesis assay was performed using an in Vitro Angiogenesis Assay Kit (Millipore), according to the protocol. ECMatrix solution was thawed overnight at $4^{\circ} \mathrm{C}$ and then mixed with $10 \times$ ECMatrix diluents. The mixture was placed into 96 -well plate and finally left to solidify at $37^{\circ} \mathrm{C}$ for $1 \mathrm{~h} .150 \mu \mathrm{l}$ medium with $10 \%$ FBS and cells $\left(3 \times 10^{4}\right)$ were added on top of the matrix solution. After incubation at $37^{\circ} \mathrm{C}$ with $5 \% \mathrm{CO}_{2}$ for $12 \mathrm{~h}$, lengths of cells that formed vascular network were observed in five randomly chosen microscopic fields by ordinary microscope (Leica), and measured by imaging analysis software (Image Pro Plus).

\section{Cytokine measurements in culture medium}

After pretreatment with sCD40L, cells were replaced with fresh EBM-2 (1ml/well) without FBS and cultured for $24 \mathrm{~h}$, and the supernatants were carefully collected. The measurements of VEGF, IL-6, soluble inter-cellular adhesion molecule-1 (sICAM) levels in cell culture medium were determined by ELISA kits (R\&D Systems), according to the manufacturer's protocol.

Animal models

PAH models were established as the classical method, and our observation lasted four weeks as ordinary standard $[13,26,27]$. Monocrotaline (MCT, Sigma, $60 \mathrm{mg} / \mathrm{kg}$ ) was subcutaneously injected into 


\section{Cellular Physiology Cell Physiol Biochem 2015;36:683-696 \\ \begin{tabular}{ll|l} 
and Biochemistry $10.1159 / 000430130$ & $\begin{array}{l}\text { (c) } 2015 \text { S. Karger AG, Basel } \\
\text { www.karger.com/cpb }\end{array}$ \\
\hline
\end{tabular} \\ Pan et al.: CD40 Pathway and Endothelial Progenitor Cells in Pulmonary Arterial Hypertension}

6 to 7 weeks old male rats. These rats were randomized into four main groups, namely: blank, vehicle, control EPC or shRNA-CD40 EPC groups. To determine the efficacies of EPCs in various environments, transplantations were taken in different period of PAH. Cell transplantation was performed as recently described [9].

Blank group received no cure $(n=24)$. Rats were randomly selected to test at day 7, 14, 21, and 28 after MCT injection. Vehicle group was further divided into three small groups, separately received phosphatebuffered saline (PBS, 200 $\mu \mathrm{L}$ ) injection through tail veins at day 7, 14 and 21 (n=6 per small group). Rats were tested at day 28.

Control EPC group received transplantation of wide type EPCs infected with Lv-NC-shRNA while shRNA-CD40 EPC group received Lv-shRNA-CD40 infected EPCs. Both control and shRNA-CD40 groups were divided into three small groups, and respectively accepted EPCs at day 7, 14, and 21 (n=6 per small group). All EPCs were injected through tail veins $\left(1 \times 10^{6}\right.$ in $\left.200 \mu \mathrm{L} \mathrm{PBS}\right)$. Rats were tested at day 28 (Fig. 1E).

All rats were anesthetized with an intraperitoneal injection of sodium pentobarbital $(30 \mathrm{mg} / \mathrm{kg})$. Right ventricular pressure (RVP) and mean pulmonary arterial pressure (mPAP) were measured with a polyethylene catheter inserted into the right ventricle (RV). After euthanization, lungs and hearts were harvested. Lungs were either frozen in liquid nitrogen or fixed with $10 \%$ methanol before sectioning. Hearts were dissected and weighted to calculate the weight ratio of the RV to left ventricle (LV) plus septum (RV/ $\mathrm{LV}+\mathrm{S}$ ratio) as an indicator of RV hypertrophy. Plasma concentration of sCD40L was tested with ELISA Kits.

\section{Histological Analysis}

The harvested lungs were fixed with $10 \%$ methanal, and embedded in paraffin. Paraffin-embedded sections ( $4 \mu \mathrm{m}$ thick) were subjected to elastic van Gieson (EVG) and hematoxylin-eosin (HE) staining for the microscopic examination. The quantitative analyses of the remodeled pulmonary arterioles (PAs), the wall area (WA) and wall thickness (WT) were measured in 30 muscular arteries per rat. The media thickness was calculated and expressed as follows: \%WT $=[($ media thickness $\times 2) /$ external diameter $] \times 100$. The wall area was calculated and expressed as follows: $\% \mathrm{WA}=(\mathrm{WA} /$ total area $) \times 100$.

\section{Tracking of transplanted EPCS}

To track the location of EPCs in PAH rat lung tissue, all transplanted EPCs were infected with GFP labeled lentivirus vectors. Fresh lungs were collected and quickly put into liquid nitrogen. The frozen tissues were then cut into serial sections and fixed. These sections were further incubated with an anti-CD31 antibody (Abcam). After staining with DAPI, lung tissue sections were directly observed under a confocal microscope. To quantitatively analyze the ratio of substitution, total lengths of green fluorescent and perimeter of vessels were measured by imaging analysis software (Image Pro Plus).

\section{Statistical analysis}

All data are presented as means \pm standard deviation (SD). The significance in differences between two groups was determined by $t$ test. Differences between group means were assessed by one-way analysis of variance (ANOVA) followed by LSD, Duncan's and S-N-K post hoc test as appropriate using SPSS version 17.0. Differences with $\mathrm{P}<0.05$ were considered statistically significant.

\section{Results}

Characterization of BM-Derived EPCS

Mononuclear cells were isolated from BM and cultured for 7 days (Fig. 2A). Basic characteristics of EPCs were double positive for DiI-Ac-LDL and FITC-UEA-I under fluorescence microscope (Fig. 2B-D). EPCs were further characterized by analyzing the cell surface markers of VEGFR2 and vWF by flow cytometry (Fig. 2E-G).

Impaired Bioactivities of EPCs Caused by SCD40L

Only those EPCs with normal bioactivities can give full play to the role of vascular repair. But even the minimum concentration of SCD $40 \mathrm{~L}(0.1 \mu \mathrm{g} / \mathrm{ml})$ in tests could reduce adhesion (control vs. sCD40L: 74.3 \pm 12.0 vs. 52.0 $\pm 10.6, \mathrm{P}<0.05$; Fig. 3B) abilities of EPCs. 


\section{Cellular Physiology Cell Physiol Biochem 2015;36:683-696 \begin{tabular}{ll|l} 
and & DOI: 10.1159/000430130 & $\begin{array}{l}\text { O 2015 S. Karger AG, Basel } \\
\text { www.karger.com/cpb }\end{array}$ \\
\hline
\end{tabular} \\ Pan et al.: CD40 Pathway and Endothelial Progenitor Cells in Pulmonary Arterial Hypertension}

Fig. 2. Identification of rat BM-derived EPCs. After being cultured for 7 days, adherent cells (A: bright) labeled with Dil-ac-LDL (B: red, exciting wave-length $543 \mathrm{~nm}$ ) and FITCUEA-I (C: green, exciting wave-length 477 nm) were observed under a fluorescence microscope $(\times 200)$. Double positive cells showed yellow in the overlay (D) were considered as early outgrowth EPCs. Endothelial-related surface antigens expressions on EPCs were determined by flow cytometry (E-G).
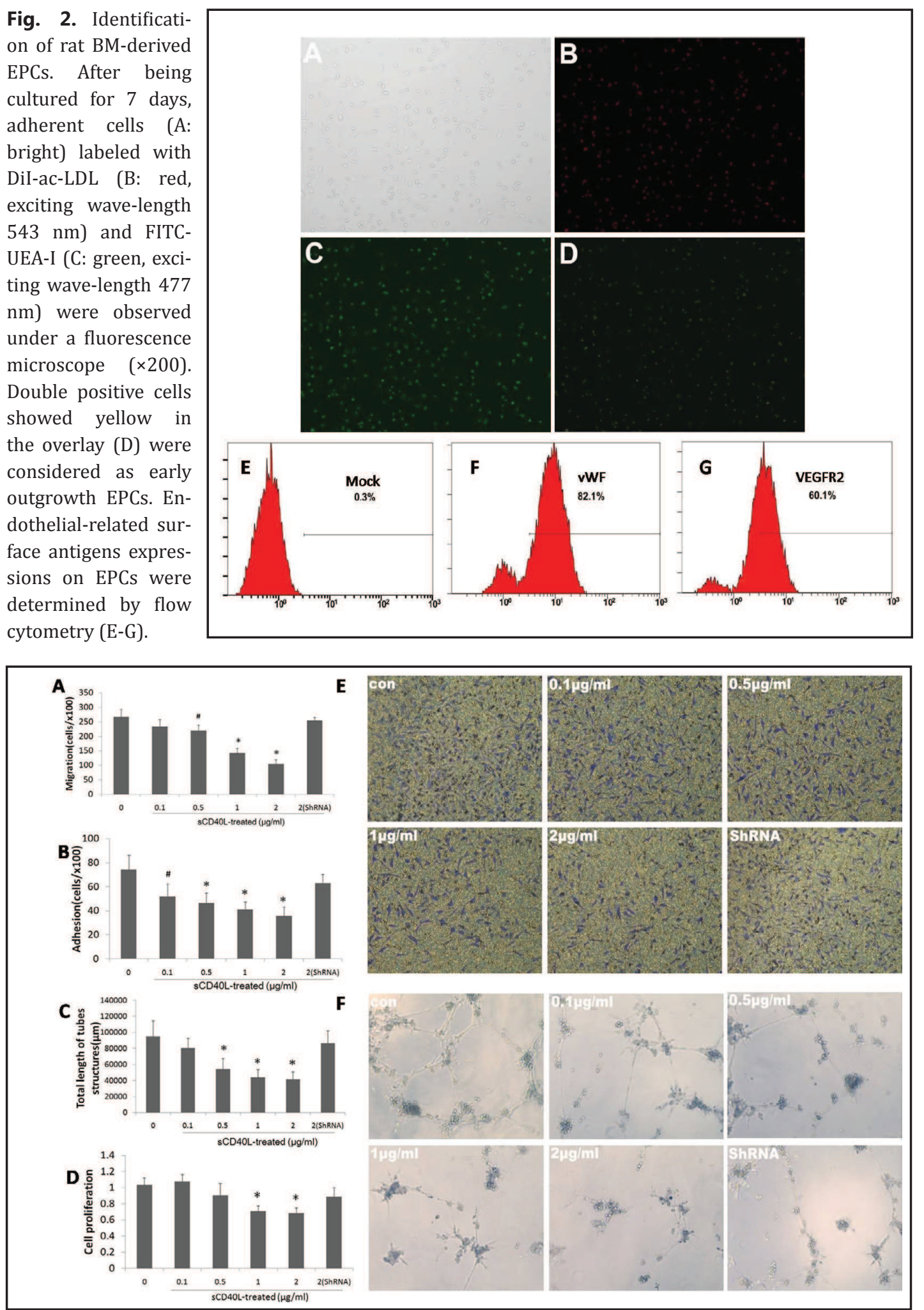

Fig. 3. sCD40L impaired bioactivities of EPCs. sCD40L (no less than $0.1 \mu \mathrm{g} / \mathrm{ml}$ ) impaired EPC adhesive capacity $(\mathrm{B}, \times 200)$. sCD40L (no less than $0.5 \mu \mathrm{g} / \mathrm{ml}$ ) impaired EPC migration $(\mathrm{A}, \mathrm{E}, \times 100)$ and in vitro tube formation abilities (C, F, $\times 100$ ). sCD40L (no less than $1 \mu \mathrm{g} / \mathrm{ml}$ ) impaired EPC proliferative capacity (D). All these effects appeared to be dose-dependent. sCD40L $(2 \mu \mathrm{g} / \mathrm{ml})$ had no effects on shRNA-CD40 EPC functions. Data are presented as means $\pm \mathrm{SD}, \mathrm{n}=3$. $\# \mathrm{P}<0.05$ vs. control $(0)$ group; ${ }^{*} \mathrm{P}<0.01$ vs. control (0) group. 


\section{Cellular Physiology Cell Physiol Biochem 2015;36:683-696 \begin{tabular}{ll|l} 
and Biochemistry & $\begin{array}{l}\text { DOI: 10.1159/000430130 } \\
\text { Published online: May 21, } 2015\end{array}$ & $\begin{array}{l}\text { (c) 2015 S. Karger AG, Basel } \\
\text { www.karger.com/cpb }\end{array}$ \\
\hline
\end{tabular} \\ Pan et al.: CD40 Pathway and Endothelial Progenitor Cells in Pulmonary Arterial Hypertension}
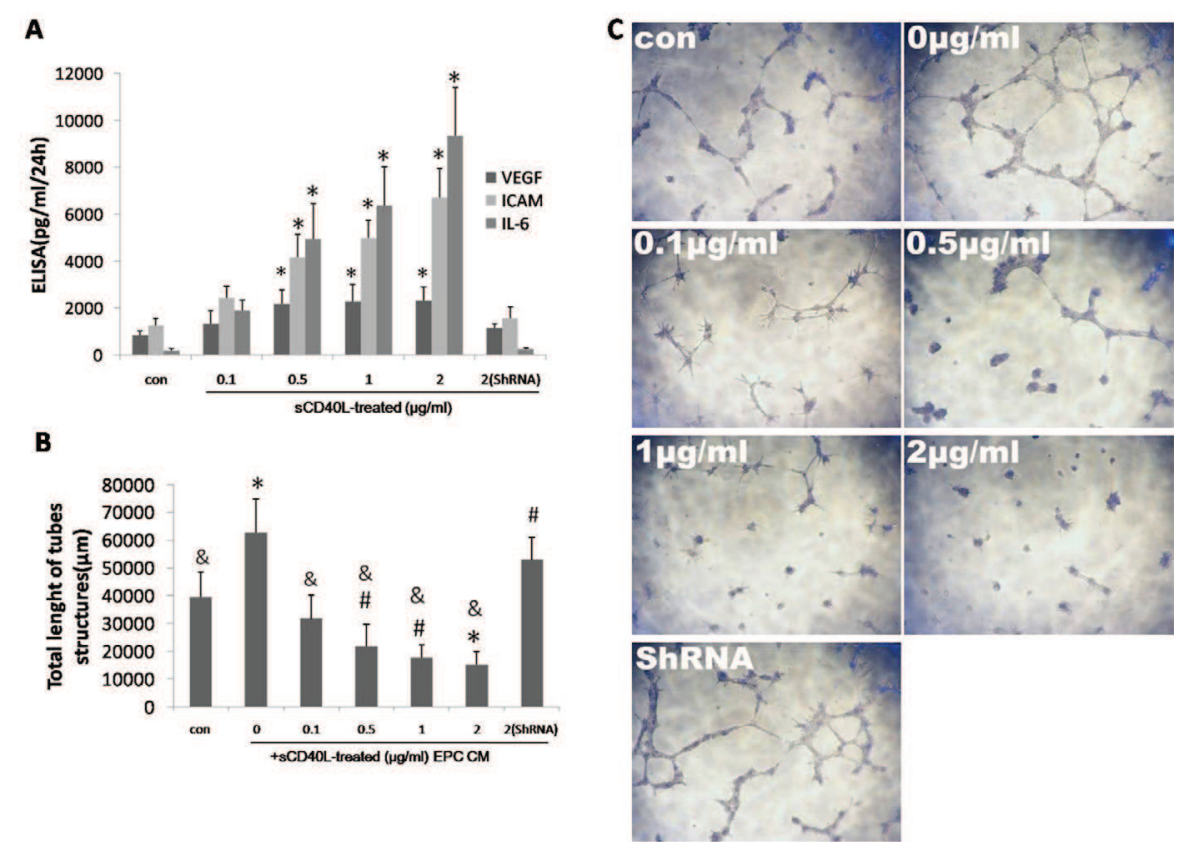

Fig. 4. sCD40L reversed EPC CM effects on EC in vitro vasculogenesis. sCD40L dose-dependently increased EPC secretions of VEGF, sICAM, and IL-6 (A). Raw EPC CM (sCD40L 0 $\mu \mathrm{g} / \mathrm{ml}$ ) apparently enhanced EC in vitro tube formation. Conversely, after pretreatment with sCD40L (no less than $0.5 \mu \mathrm{g} / \mathrm{ml}$ ), EPC CM seriously hampered it. sCD40L $(2 \mu \mathrm{g} / \mathrm{ml})$ had no effects on shRNA-CD40 EPC paracrine functions $(\mathrm{B}, \mathrm{C} \times 100)$. Data are presented as means $\pm \mathrm{SD}, \mathrm{n}=3 .{ }^{*} \mathrm{P}<0.01$ vs. control; $\# \mathrm{P}<0.05$ vs. control; $\& \mathrm{P}<0.01$ vs. 0 group (the group treated with $0 \mu \mathrm{g} / \mathrm{ml} \mathrm{sCD} 40 \mathrm{~L}$-treated EPC CM).

sCD40L $(0.5 \mu \mathrm{g} / \mathrm{ml})$ could apparently decrease migration (control vs. sCD40L: $267.3 \pm 25.3$ vs. $220.0 \pm 18.2, \mathrm{P}<0.05$; Fig. $3 \mathrm{~A}, 3 \mathrm{E}$ ) and in vitro tube formation of EPCs (control vs. SCD40L: $95098.0 \pm 19425.8$ vs. $54029.3 \pm 13459.6$, P $<0.01$; Fig. 3C, 3F). Proliferation abilities of EPCs were impaired in a higher level of sCD 40L (control vs. $1 \mu \mathrm{g} / \mathrm{ml} \mathrm{sCD} 40 \mathrm{~L}: 1.0 \pm 0.1$ vs. $0.7 \pm 0.1$, $\mathrm{P}<0.01$; Fig. 3D). All these effects appeared to be dose-dependent. sCD40L $(2 \mu \mathrm{g} / \mathrm{ml})$ had no effects on shRNA-CD40 EPC functions.

Enhanced Paracrine Functions of EPCs Caused by sCD40L

Paracrine functions of EPCs also had a huge impact on treatment outcomes. sCD40L $(0.5 \mu \mathrm{g} / \mathrm{ml})$ could apparently increase the secretion of IL-6, VEGF, and sICAM of EPCs, and these effects appeared to be dose-dependent (Fig. 4A). IL-6 (control vs. $2 \mu \mathrm{g} / \mathrm{ml} \mathrm{sCD40L:}$ $206.7 \pm 70.6$ vs. $9356.4 \pm 2061.9, \mathrm{P}<0.01$ ) had an obvious higher rise than VEGF (control vs. $2 \mu \mathrm{g} / \mathrm{ml}$ sCD40L: $842.6 \pm 190.5$ vs. $2323.3 \pm 589.5, \mathrm{P}<0.01$ ) and sICAM (control vs. $2 \mu \mathrm{g} / \mathrm{ml}$ sCD40L: $1258.1 \pm 300.1$ vs. $6724.1 \pm 1235.1, \mathrm{P}<0.01)$. sCD40L $(2 \mu \mathrm{g} / \mathrm{ml})$ had no effects on shRNA-CD40 EPC paracrine functions.

Reversed Effects ofEPC-Derived Conditioned Medium (EPCCM) on ECin vitro Vasculogenesis Caused by sCD $40 \mathrm{~L}$

We chose rat pulmonary microvascular EC line to study the effects of EPC CM on EC tube formation potential. ECs were cultured in EBM-2 with 10\% FBS in the beginning. EPCs were pretreated with sCD40L $(0,0.1,0.5,1$ or $2 \mu \mathrm{g} / \mathrm{ml})$ at day 7 . After $24 \mathrm{~h}$, EPCs were replaced with fresh medium (1ml/well), and continued to culture for $24 \mathrm{~h}$. Then EPC CM was carefully collected and added to culture ECs instead of EBM-2 for 24h. Finally, ECs were collected and tested using in vitro Angiogenesis Assay Kit. We observed that the blend of growth factors in EPC CM could obviously enhance EC in vitro tube formation function (control vs. EPC 


\section{Cellular Physiology Cell Physiol Biochem 2015;36:683-696 \begin{tabular}{ll|l}
\hline DOI: 10.1159/000430130 & $\begin{array}{l}\text { C 2015 S. Karger AG, Basel } \\
\text { www.karger.com/cpb }\end{array}$ \\
\hline
\end{tabular} \\ Pan et al.: CD40 Pathway and Endothelial Progenitor Cells in Pulmonary Arterial Hypertension}

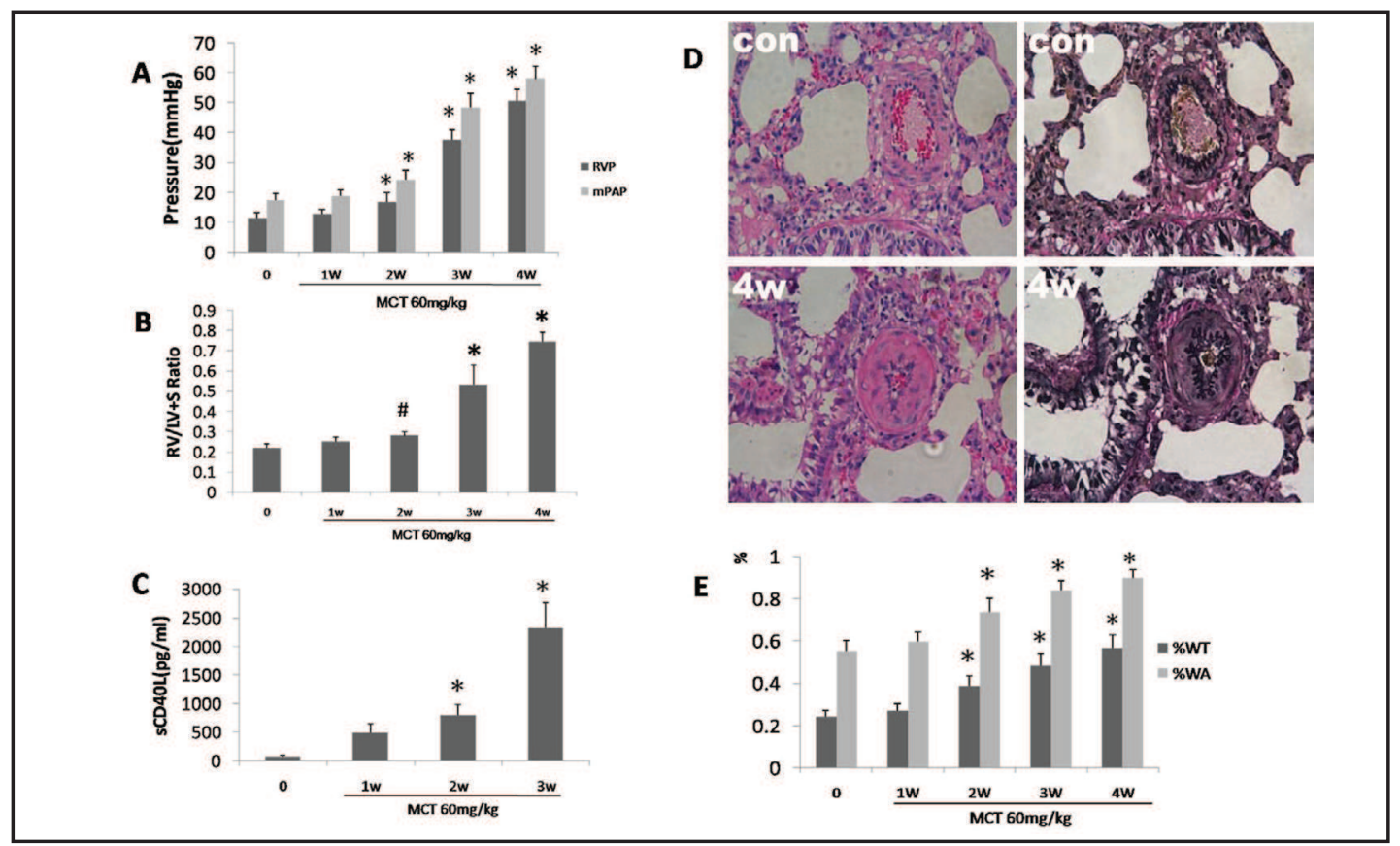

Fig. 5. Pathological changes of MCT induced rat PAH. Every week after MCT injection, six rats were anesthetized and euthanized separately to detect the pathological changes. RVP, mPAP (A), and RV/ LV+S ratio (B) were gradually elevated and became apparent since the second week. SCD40L levels in rat serum were also time-dependently elevated (C). Lung sections were collected for HE and EVG staining (D, ×400). Media thickness, external diameter, lumen area and the total area were measured. \%WT and \%WA were calculated to assess the extent of vascular remodeling (E). Data are presented as means $\pm S D, n=6 . \# P<0.05$ vs. control (0) group; ${ }^{*} \mathrm{P}<0.01$ vs. control (0) group.

CM: $39432.3 \pm 9006.0$ vs. $62527.3 \pm 12352.8, \mathrm{P}<0.01)$. On the contrary, after pretreatment with sCD40L $(0.5 \mu \mathrm{g} / \mathrm{ml})$, EPC CM seriously hampered it (control vs. EPC CM+sCD40L: $39432.3 \pm 9006.0$ vs. $21816.0 \pm 7917.1, \mathrm{P}<0.01$ ). This effect appeared to be dose-dependent (Fig. 4B).

\section{Monitoring of Pathological Changes of PAH}

To investigate the impact of various pathological surroundings on EPC efficacies, and seek the optimal time window for cell transplantation, RVP, mPAP (Fig. 5A), RV/ LV+S ratio (Fig. 5B), and serum sCD40L levels (Fig. 5C) were tested, and tissue samples (Fig. 5DE) were collected every 7 days. Fourteen days after MCT injection, we noticed significant changes in all targets tested, demonstrating the successful establishment of rat PAH model. Serum levels of sCD40L gradually elevated as the disease progressed.

\section{Efficacies of EPC Therapies and Superiorities of shRNA-CD40 EPCS}

Control EPCs and shRNA-CD40 EPCs were injected via tail vein at day 7, 14, and 21. All EPC transplanted groups achieved therapeutic effects comparing to blank or vehicle groups. By comparing the two types of EPCs, we found that shRNA-CD40 EPCs played a more effective and enduring role than control ones injected at the same time (Fig. 6A-D). Within control EPC groups, effects of 3-week group were apparently better than those of 1 and 2-week groups. It indicated that benefits of raw EPCs wore off over time. On the contrary, shRNA-CD40 EPC groups had more stable effects, for there were no significant differences among 1, 2, 3-week shRNA-CD40 groups. There is no difference between vehicle groups and blank groups (not shown in our results). 


\section{Cellular Physiology Cell Physiol Biochem 2015;36:683-696 \begin{tabular}{l|l} 
DOI: 10.1159/000430130 & $\begin{array}{l}\text { O 2015 S. Karger AG, Basel } \\
\text { www.karger.com/cpb }\end{array}$ \\
\hline
\end{tabular} \\ Pan et al.: CD40 Pathway and Endothelial Progenitor Cells in Pulmonary Arterial Hypertension}

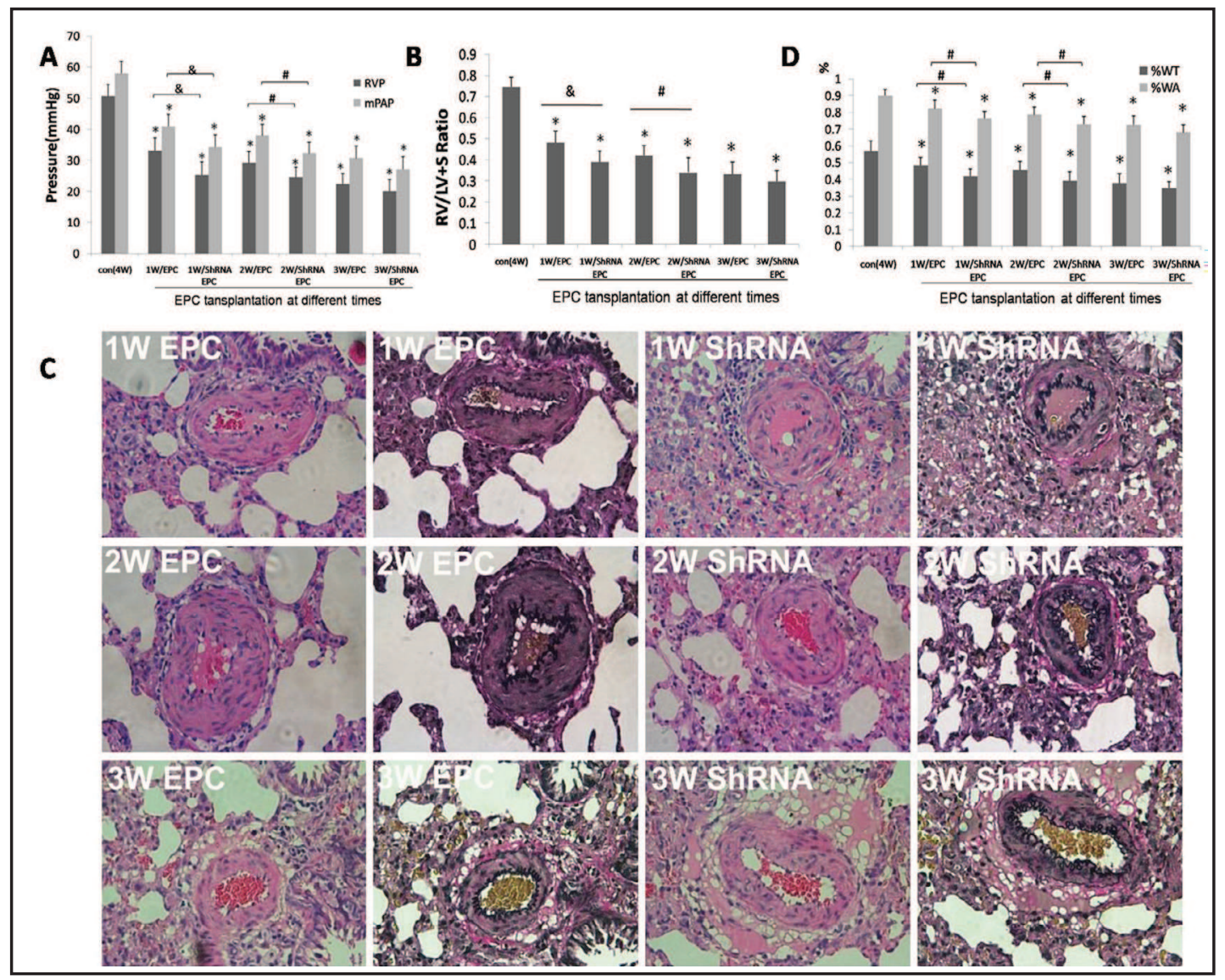

Fig. 6. Effects of transplantations with two types of EPCs on PAH. Tested at day 28, rat RVP, mPAP (A), RV/ $\mathrm{LV}+\mathrm{S}$ ratio (B), and \%WT, \%WA (D) were decreased in different degrees after treatment with either control EPCs or shRNA-CD40 EPCs comparing to control group (MCT only). shRNA-CD40 EPCs played more effective and stable roles than control EPCs injected at the same time. Lung sections were collected for HE and EVG staining $(C, \times 400)$. Data are presented as means $\pm S D, n=6 .{ }^{*} \mathrm{P}<0.01$ vs. control; $\& \mathrm{P}<0.01$ shRNA-CD40 EPC vs. control EPC; \#P<0.05 shRNA-CD40 EPC vs. control EPC.

\section{More Accurate Location of Transplanted shRNA-CD40 EPCs}

We believed that only those EPCs bound in intima were therapeutic ones. Control EPCs, shRNA-CD40 EPCs, and their proliferating ones labeled with green fluorescence could be found in lung tissue frozen sections under confocal microscope (Fig. 7A). Most of the GFP' cells were positive for CD31, indicating their endothelial character (Fig. 7B). We further noticed that more shRNA-CD40 EPCs combined into endothelium, but less into adventitia and media, comparing to control EPCs injected at the same time (Fig. 7C). In intima, both of the two types of EPCs kept on proliferating. In adventitia and media, the amount of shRNACD40 EPCs gradually dwindled, while control EPCs showed a growing tendency after initial minor reductions.

\section{Discussion}

Impairment of ECs in vascular intima is considered to play an initial and critical role in the processes of pathological changes in PAH [20]. EPCs can differentiate into mature ECs, integrate into pulmonary vascular endothelium, directly replace the impaired ECs, and accelerate in situ endothelialization [28]. However, bioactivities of EPCs are susceptible to enhanced oxidative stress, possibly as a result of systemic or localised inflammatory 


\section{Cellular Physiology Cell Physiol Biochem 2015;36:683-696 \\ \begin{tabular}{ll|l} 
and Biochem 10.1159/000430130 & $\begin{array}{l}\text { C 2015 S. Karger AG, Basel } \\
\text { www.karger.com/cpb }\end{array}$ \\
\hline
\end{tabular} \\ Pan et al.: CD40 Pathway and Endothelial Progenitor Cells in Pulmonary Arterial Hypertension}

A
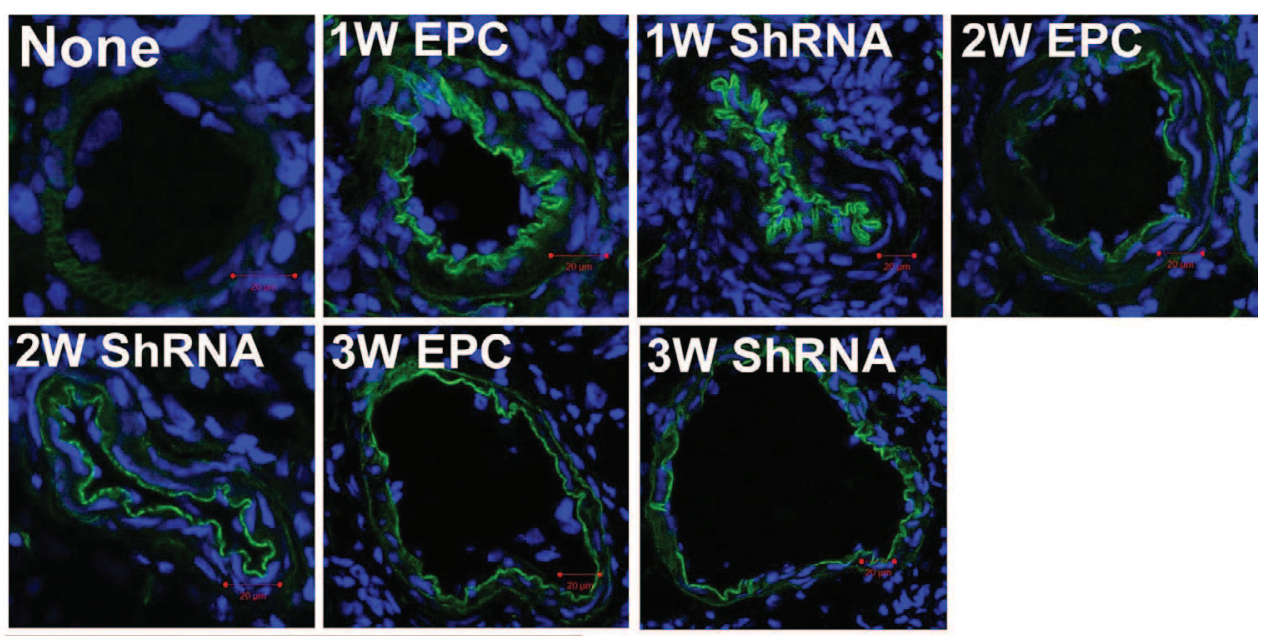

B
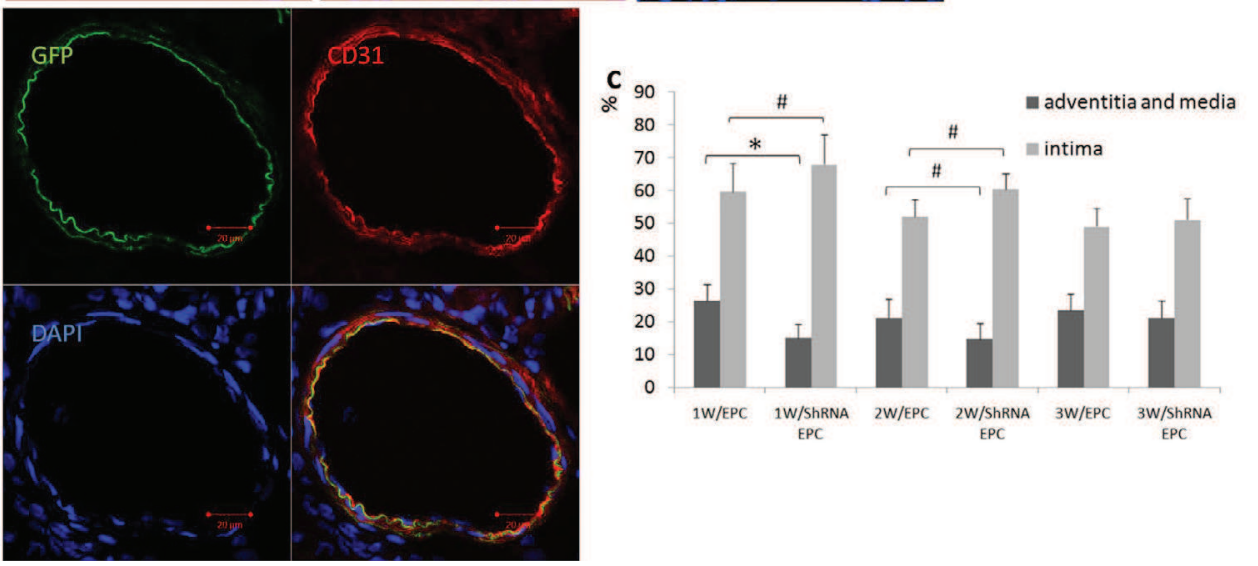

Fig. 7. Tracking of transplanted EPCs. All lung tissues were collected at day 28 after MCT injection. Transplanted EPCs or their expanded ones were labeled with GFP. Nucleus stained with DAPI showed blue under confocal microscope (A). Most of $\mathrm{GFP}^{+}$cells were positive for CD31 (B). Lengths of green fluorescent in adventitia, media and intima were measured as well as the inner and outer circumferences of the vessels. shRNA-CD40 EPCs had a higher replacement ratio in intima, but a lower ratio in adventitia and media than control EPCs injected at the same time (C). Data are presented as means $\pm \mathrm{SD}, \mathrm{n}=6$. ${ }^{*} \mathrm{P}<0.01$ shRNA-CD40 EPC vs. control EPC; \#P<0.05 shRNA-CD40 EPC vs. control EPC.

responses [19]. Clinical trials revealed that high levels of sCD40L might enhance inflammation and restenosis [29]. Early EPCs expressed CD40 signalling adaptors molecules TRAF1, 2 and 3, but not TRAF5 and TRAF6. Stimulation of EPCs with sCD40L increased the expression of TRAF1, binding of TRAF2 to CD40, and phosphorylation of p38 mitogen activated protein kinase [30]. The activation of the CD40 receptor had been reported to critically affect endothelial regeneration by increasing endothelial reactive oxygen species of ECs and EPCs $[24,31]$. We found that sCD40L dose-dependently impaired EPC migration, adhesion, proliferation, and in vitro vasculogenesis functions. All these functions are closely related to the repair activities of EPCs.

On the other hand, EPC CM has the potential capacity to support the functions of resident ECs in a paracrine fashion in disease settings. Stefano et al. highly valued the paracrine effects of EPCs and they demonstrated that EPC CM significantly inhibited apoptosis of ECs and promoted angiogenesis in rat aortic ring assay [3]. Cell free administration by EPC CM injection could achieve an angiogenic effect equivalent to EPC therapy in rat model of chronic hindlimb ischemia [3]. However, Zhang et al. draw our attentions to negative roles 


\section{Cellular Physiology Cell Physiol Biochem 2015;36:683-696

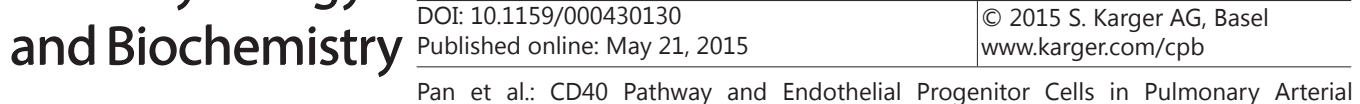 Hypertension}

of EPCs in releasing MCP-1, IL-8, and RANTES, which was significantly augmented when exposed to pro-inflammatory cytokine [32]. We also observed the powerful protective effects of EPC CM on EC functions in normal environment. But after pretreatment of sCD40L, combined effects of EPC CM on ECs were reversed, from protection to impairment. We demonstrated that activation of CD40/CD40L system stimulated the strong paracrine ability of early outgrowth EPCs to release pro-inflammatory factors at least IL-6 and sICAM. Khzam et al. also revealed that sCD40L increased MMP-9 release of early EPCs via the p38 MAPK signaling pathway [30]. Local chronic inflammatory response may further perpetuate vascular remodeling $[15,17]$.

Overall, in agreement with previous researches, our data revealed the negative influences of sCD40L on EPCs. In vivo environments of cardiovascular diseases are more complicated and hostile. Work over the past decades has proved that pathological microenvironment may invalidate transplanted EPCs [12, 19, 20,33]. We checked the presentations of raw EPCs in PAH surroundings, and further confirmed the role of CD40 pathway by using CD40 knockdown shRNA-CD40 EPCs.

According to in vitro results, groups with EPC transplantation taken at later stage of PAH with higher sCD40L levels might get fewer benefits. However, we observed that EPCs could significantly improve the disease conditions of PAH rats, even transplanted at day 21, the advanced stage of PAH. It indicated the great biological activity and repair effects of EPCs. Most importantly, we observed that vessels with more EPCs residing in endothelium had less degrees of vascular remodeling in the same rat lung, further confirmed the efficacies of EPC therapies.

However, that did not mean the elevated levels of sCD40L in serum did little to the transplanted EPCs. Damages caused by diseased conditions to EPCs were chronic, mainly showed in the decline of benefits of wild type EPCs. In our study, comparing within control EPC groups, effects of EPCs peaked within one week after transplantation with all targets apparently improved. But two weeks later, cell efficacies gradually waned with rats' situations evidently deteriorated, while the amounts of EPCs in intima kept growing. There were some direct reasons causing this problem. Firstly, the actions of EPCs replacing impaired ECs were one-time activities. Once located, EPCs could not move to newly impaired area freely. They gradually differentiated into mature ECs exhibiting a lower proliferative index [14]. Secondly, based on in vitro results, long-term exposure to pathological microenvironment led to great changes in the tube formation related functions and paracrine effects of transplanted EPCs. An inflammation-based secretion might further affect activities of surrounding ECs and deeper vascular cells. In conclusion, transplanted EPCs gradually lost the advantages as healthy and positive cells, and became as vulnerable as resident ECs. Therefore, pure EPC transplantation cannot meet the requirements of chronic diseases.

Turning off CD40 pathway made EPCs better fit in the in vivo hostile environment [24, 34], and we were the first to confirm it in PAH model. Firstly, transplantation of shRNACD40 EPCs played a better role as compared to control EPCs transplanted at the same time. More importantly, shRNA-CD40 EPCs could keep the favorable effects. We concluded the advantages of shRNA-CD40 EPCs in two aspects: a better endothelialization related function of themselves and less secretion of inflammatory cytokines in the long run. Statins which were reported to decrease expression of CD40L could enhance mobilization and reduce the release of MCP-1 up to 70\% of EPCs [32, 35].

Moreover, we must pay great attention to the location of transplanted EPCs. The ability of EPCs to form vascular network also gives them double identity to constitute vasa vasorum $[14,16]$. Marked thickening of the pulmonary vessel wall is often accompanied by an apparent increase in the density of vasa vasorum in adventitia and media $[14,16]$. Enhanced vasa vasorum neovascularization in adventitia facilitates the "outside-in" inflammatory response, by increasing infiltration and homing of circulating progenitors and inflammatory cells, not only of the adventitia, but subsequently in the media and intima, contributing to the development of vascular remodeling in PAH $[16,18]$. 


\section{Cellular Physiology Cell Physiol Biochem 2015;36:683-696 \\ \begin{tabular}{ll|l}
\hline DOI: 10.1159/000430130 & $\begin{array}{l}\text { C 2015 S. Karger AG, Basel } \\
\text { www.karger.com/cpb }\end{array}$ \\
\hline
\end{tabular} \\ Pan et al.: CD40 Pathway and Endothelial Progenitor Cells in Pulmonary Arterial Hypertension}

Our results demonstrated that interruption of CD40 pathway did not hamper the combination of transplanted EPCs into the intima. Notably, comparing to control EPCs, infused shRNA-CD40 EPCs seemed to reside in endothelium more precisely rather than in other places. But it was hard to tell these engrafted EPCs in vessels were transplanted ones or their progenies. In intima, genetically modified EPCs with improved bio-functions could proliferate and repair injury better against the hostile environment. In adventitia and media, growth of vasa vasorums needed stimulations such as hypoxia, inflammation and high pressure $[14,36]$. We observed a growth trend in intima but a downtrend in adventitia and media in shRNA-CD40 EPC groups, indicating the regulations of environment on EPC distributions. So transplanted EPCs ameliorated the disease conditions, and in turn, being kept on the right track by the improved conditions.

Our study was time-limited as a short term animal research, and the results only provided us an impetus for further clinical investigations. Still, the specific plans aiming at blocking CD40 pathway with drugs or genetic tools that can be applied in PAH treatments remain to be explored in the future.

In general, the present study reaffirmed the application of EPC therapy and revealed the superiorities of CD40 knockdown EPCs in PAH treatment. We recommend that pure EPC transplantations are inadequate for chronic diseases. Therapeutically shutting down CD40 pathway may be a new choice to achieve a better and longer lasting effect of EPC therapy in future PAH clinical applications.

\section{Acknowledgments}

This work was supported by the National Natural Science Foundation of China (grant number NSFC 81370155, 81270180), and Zhejiang Provincial Science Natural Science Foundation for Distinguished Young Scholars (grant number LR12H01002).

\section{Disclosure Statement}

None.

\section{References}

1 Yang JX, Pan YY, Zhao YY, Wang XX: Endothelial progenitor cell-based therapy for pulmonary arterial hypertension. Cell Transplant 2013;22:1325-1336.

2 Yoder MC: Endothelial progenitor cell: a blood cell by many other names may serve similar functions. J Mol Med (Berl) 2013;91:285-295.

3 Di Santo S, Yang Z, Wyler von Ballmoos M, Voelzmann J, Diehm N, Baumgartner I, Kalka C: Novel cell-free strategy for therapeutic angiogenesis: in vitro generated conditioned medium can replace progenitor cell transplantation. PLoS One 2009;4:e5643.

4 Marsboom G, Janssens S: Endothelial progenitor cells: new perspectives and applications in cardiovascular therapies. Expert Rev Cardiovasc Ther 2008;6:687-701.

5 Nagaya N, Kangawa K, Kanda M, Uematsu M, Horio T, Fukuyama N, Hino J, Harada-Shiba M, Okumura H, Tabata Y, Mochizuki N, Chiba Y, Nishioka K, Miyatake K, Asahara T, Hara H, Mori H: Hybrid cell-gene therapy for pulmonary hypertension based on phagocytosing action of endothelial progenitor cells. Circulation 2003;108:889-895.

6 Zhao Q Liu Z, Wang Z, Yang C, Liu J, Lu J: Effect of prepro-calcitonin gene-related peptide-expressing endothelial progenitor cells on pulmonary hypertension. Ann Thorac Surg 2007;84:544-552.

7 Zhao YD, Courtman DW, Deng Y, Kugathasan L, Zhang Q, Stewart DJ: Rescue of monocrotaline-induced pulmonary arterial hypertension using bone marrow-derived endothelial-like progenitor cells: efficacy of combined cell and eNOS gene therapy in established disease. Circ Res 2005;96:442-450. 


\section{Cellular Physiology Cell Physiol Biochem 2015;36:683-696 \begin{tabular}{ll|l} 
and & DOI 10.1159/000430130 & $\begin{array}{l}\text { C) 2015 S. Karger AG, Basel } \\
\text { www.karger.com/cpb }\end{array}$ \\
\hline
\end{tabular} Pan et al.: CD40 Pathway and Endothelial Progenitor Cells in Pulmonary Arterial Hypertension}

8 Sun CK, Lee FY, Sheu JJ, Yuen CM, Chua S, Chung SY, Chai HT, Chen YT, Kao YH, Chang LT, Yip HK: Early combined treatment with cilostazol and bone marrow-derived endothelial progenitor cells markedly attenuates pulmonary arterial hypertension in rats. J Pharmacol Exp Ther 2009;330:718-726.

9 Sun CK, Lin YC, Yuen CM, Chua S, Chang LT, Sheu JJ, Lee FY, Fu M, Leu S, Yip HK: Enhanced protection against pulmonary hypertension with sildenafil and endothelial progenitor cell in rats. Int J Cardiol 2012;162:4558.

10 Zhu JH, Wang XX, Zhang FR, Shang YP, Tao QM, Zhu JH, Chen JZ: Safety and efficacy of autologous endothelial progenitor cells transplantation in children with idiopathic pulmonary arterial hypertension: open-label pilot study. Pediatr Transplant 2008;12:650-655.

11 Wang XX, Zhang FR, Shang YP, Zhu JH, Xie XD, Tao QM, Zhu JH, Chen JZ: Transplantation of autologous endothelial progenitor cells may be beneficial in patients with idiopathic pulmonary arterial hypertension: a pilot randomized controlled trial. J Am Coll Cardiol 2007;49:1566-1571.

12 Marsboom G, Pokreisz P, Gheysens O, Vermeersch P, Gillijns H, Pellens M, Liu X, Collen D, Janssens S: Sustained endothelial progenitor cell dysfunction after chronic hypoxia-induced pulmonary hypertension. Stem Cells 2008;26:1017-1026.

13 Mirsky R, Jahn S, Koskenvuo JW, Sievers RE, Yim SM, Ritner C, Bernstein HS, Angeli FS, Boyle AJ, De Marco T, Yeghiazarians Y: Treatment of pulmonary arterial hypertension with circulating angiogenic cells. Am J Physiol Lung Cell Mol Physiol 2011;301:L12-19.

14 Davie NJ, Crossno JT Jr, Frid MG, Hofmeister SE, Reeves JT, Hyde DM, Carpenter TC, Brunetti JA, McNiece IK, Stenmark KR: Hypoxia-induced pulmonary artery adventitial remodeling and neovascularization: contribution of progenitor cells. Am J Physiol Lung Cell Mol Physiol 2004;286:L668-678.

15 Tuder RM: How do we measure pathology in PAH (lung and RV) and what does it tell us about the disease. Drug Discov Today 2014;19:1257-1263.

16 Nijmeh H, Balasubramaniam V, Burns N, Ahmad A, Stenmark KR, Gerasimovskaya EV: High proliferative potential endothelial colony-forming cells contribute to hypoxia-induced pulmonary artery vasa vasorum neovascularization. Am J Physiol Lung Cell Mol Physiol 2014;306:L661-671.

17 Li M, Riddle SR, Frid MG, El Kasmi KC, McKinsey TA, Sokol RJ, Strassheim D, Meyrick B, Yeager ME, Flockton AR, McKeon BA, Lemon DD, Horn TR, Anwar A, Barajas C, Stenmark KR: Emergence of fibroblasts with a proinflammatory epigenetically altered phenotype in severe hypoxic pulmonary hypertension. J Immunol 2011;187:2711-2722.

18 Savai R, Pullamsetti SS, Kolbe J, Bieniek E, Voswinckel R, Fink L, Scheed A, Ritter C, Dahal BK, Vater A, Klussmann S, Ghofrani HA, Weissmann N, Klepetko W, Banat GA, Seeger W, Grimminger F, Schermuly RT: Immune and inflammatory cell involvement in the pathology of idiopathic pulmonary arterial hypertension. Am J Respir Crit Care Med 2012;186:897-908.

19 Lin CP, Lin FY, Huang PH, Chen YL, Chen WC, Chen HY, Huang YC, Liao WL, Huang HC, Liu PL, Chen YH: Endothelial progenitor cell dysfunction in cardiovascular diseases: role of reactive oxygen species and inflammation. Biomed Res Int 2013;2013:845037.

20 Asosingh K, Farha S, Lichtin A, Graham B, George D, Aldred M, Hazen SL, Loyd J, Tuder R, Erzurum SC: Pulmonary vascular disease in mice xenografted with human BM progenitors from patients with pulmonary arterial hypertension. Blood 2012;120:1218-1227.

21 Damas JK, Otterdal K, Yndestad A, Aass H, Solum NO, Froland SS, Simonsen S, Aukrust P, Andreassen AK: Soluble CD40 ligand in pulmonary arterial hypertension: possible pathogenic role of the interaction between platelets and endothelial cells. Circulation 2004;110:999-1005.

22 Hassan GS, Merhi Y, Mourad W: CD40 ligand: a neo-inflammatory molecule in vascular diseases. Immunobiology 2012;217:521-532.

23 Antoniades C, Bakogiannis C, Tousoulis D, Antonopoulos AS, Stefanadis C: The CD40/CD40 ligand system: linking inflammation with atherothrombosis. J Am Coll Cardiol 2009;54:669-677.

24 Hristov M, Gumbel D, Lutgens E, Zernecke A, Weber C: Soluble CD40 ligand impairs the function of peripheral blood angiogenic outgrowth cells and increases neointimal formation after arterial injury. Circulation 2010;121:315-324.

25 Zhang B, Wu T, Chen M, Zhou Y, Yi D, Guo R: The CD40/CD40L system: a new therapeutic target for disease. Immunol Lett 2013;153:58-61. 


\section{Cellular Physiology Cell Physiol Biochem 2015;36:683-696 \\ \begin{tabular}{ll|l} 
and Biochemistry $10.1159 / 000430130$ & $\begin{array}{l}\text { Published online: May 21, } 2015 \\
\text { www.karger.com/cpb }\end{array}$ \\
\cline { 2 - 3 }
\end{tabular}}

Pan et al.: CD40 Pathway and Endothelial Progenitor Cells in Pulmonary Arterial Hypertension

26 Chaumais MC, Ranchoux B, Montani D, Dorfmuller P, Tu L, Lecerf F, Raymond N, Guignabert C, Price L, Simonneau G, Cohen-Kaminsky S, Humbert M, Perros F: N-acetylcysteine improves established monocrotaline-induced pulmonary hypertension in rats. Respir Res 2014;15:65.

27 Ormiston ML, Deng Y, Stewart DJ, Courtman DW: Innate immunity in the therapeutic actions of endothelial progenitor cells in pulmonary hypertension. Am J Respir Cell Mol Biol 2010;43:546-554.

28 de Mel A, Jell G, Stevens MM, Seifalian AM: Biofunctionalization of biomaterials for accelerated in situ endothelialization: a review. Biomacromolecules 2008;9:2969-2979.

29 Cipollone F, Ferri C, Desideri G, Paloscia L, Materazzo G, Mascellanti M, Fazia M, Iezzi A, Cuccurullo C, Pini B, Bucci M, Santucci A, Cuccurullo F, Mezzetti A: Preprocedural level of soluble CD40L is predictive of enhanced inflammatory response and restenosis after coronary angioplasty. Circulation 2003;108:27762782.

30 Bou Khzam L, Boulahya R, Abou-Saleh H, Hachem A, Zaid Y, Merhi Y: Soluble CD40 ligand stimulates the pro-angiogenic function of peripheral blood angiogenic outgrowth cells via increased release of matrix metalloproteinase-9. PLoS One 2013;8:e84289.

31 Urbich C, Dernbach E, Aicher A, Zeiher AM, Dimmeler S: CD40 Ligand Inhibits Endothelial Cell Migration by Increasing Production of Endothelial Reactive Oxygen Species. Circulation 2002;106:981-986.

32 Zhang Y, Ingram DA, Murphy MP, Saadatzadeh MR, Mead LE, Prater DN, Rehman J: Release of proinflammatory mediators and expression of proinflammatory adhesion molecules by endothelial progenitor cells. Am J Physiol Heart Circ Physiol 2009;296:H1675-1682.

33 Zhu JH, Chen JZ, Wang XX, Xie XD, Sun J, Zhang FR: Homocysteine accelerates senescence and reduces proliferation of endothelial progenitor cells. J Mol Cell Cardiol 2006;40:648-652.

34 Bou Khzam L, Hachem A, Zaid Y, Boulahya R, Mourad W, Merhi Y: Soluble CD40 ligand impairs the antiplatelet function of peripheral blood angiogenic outgrowth cells via increased production of reactive oxygen species. Thromb Haemost 2013;109:940-947.

35 Ye H, He F, Fei X, Lou Y, Wang S, Yang R, Hu Y, Chen X: High-dose atorvastatin reloading before percutaneous coronary intervention increased circulating endothelial progenitor cells and reduced inflammatory cytokine expression during the perioperative period. J Cardiovasc Pharmacol Ther 2014;19:290-295.

36 Mulligan-Kehoe MJ, Simons M: Vasa vasorum in normal and diseased arteries. Circulation 2014;129:25572566. 